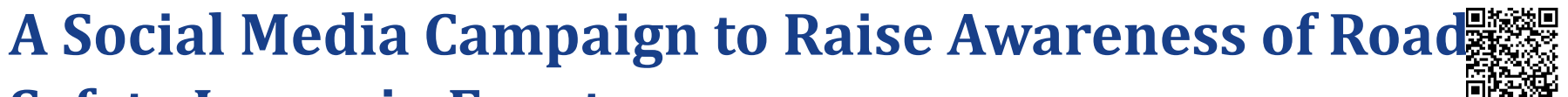 Safety Issues in Egypt
}

\author{
*Laith R Sultan \\ Department of Public Health, John Hopkins University, USA
}

Submission: April 25, 2017; Published: April 27, 2017

*Corresponding author: Laith R Sultan, Department of Public Health, John Hopkins University, Baltimore, Maryland, USA,

Email: Isultan@mail.med.upenn.edu

\section{Goal of the Intervention}

The mortality and morbidity rates related to road safety issues are very high in Egypt [1], as it is ranked as a country with one of the highest rates of mortality in the world due to road traffic crashes. Traffic accidents are the main cause of death in the country [2]. The proposed intervention is to establish a very large and highly effective social media campaign that employs highly influential social media personalities. The purpose of this campaign is to effectively raise the awareness of population in Egypt in to safety road issues with an ultimate objective to decrease the number of road injuries and fatalities.

\section{Indicators}

The main indicators for the success of this campaign will be divided into early and late indicators. Early indicators include the level of participation in the social media pages from population, the level of participation in the social media pages from social media personalities. In addition to the number and nature of live events held. The level of media coverage for the campaign also reflects its progress and represents an important indicator. Late indicators to be evaluated include: number of accidents, number of injuries and fatalities, and sensible changes in behavior and attitude towards road safety measures.

\section{Data Collection}

The early indicators are significant to evaluate to assess if the campaign is moving in the right direction. The participation of personals will be evaluated and measured in terms of number, quality and type of participation. Also assessing the number of participants from the population in social media pages, which represent the base for this campaign. In addition to number, socio-demographic factors like Age, gender, education background, and geographical distribution etc. is important to assess. If the campaign is not showing satisfactory progress for any reason, fast revision is required to overcome these issues. Monitoring media coverage for the campaign is necessary to estimate the campaign effect, attention acquired by audience and power. Furthermore, monitoring the progress of live events held in terms of frequency, distribution, number of participants, geographical distribution and participation from stakeholders, all are necessary to determine if the campaign is moving in the right direction as well.

Incidence rates of injuries and fatalities will be acquired from the ministry of health and ministry of interior as well as WHO. Assessment of changes in rates of accidents in the post campaign period is also crucial to determine its success. These statistics can be acquired from reports by ministry of transportation and ministry of interior. Such statistics should cover all the country. A principal indicator in our study, which is the expected change in behavior and attitude of drivers and pedestrians to road safety measures, will be monitored and determined by observational type of study. The observation team consists of two researchers and multiple volunteers. These researchers will be responsible for directing the study on field. The team will be supplied with radars for speeding measurement, and high quality cameras for detecting if drivers are wearing the belts and taking into consideration the safety issues.

The team members will be monitoring certain locations that were reported to have high number of accidents as well major bridges and highways. Monitoring will be for 1 year after the end of the campaign. The monitoring activities will be for 3-4 days a week, three times each day for 60-90 minutes during the morning, afternoon and evening. Also pedestrians will be monitored at road cross-area and traffic lights. Monitoring will be by a team that will be devoted for 1 week for this mission and replaced with another team every other week. Measurements will be in the same manner as for vehicles. Team members and volunteers will work on multiple surveys online or on site through asking multiple-choice questions to assess the change in behavior, awareness and understanding of population about road safety issues importance (Table 1). 
Table 1: The number of insurance policies obtained by drivers could be acquired from ministry of transportation/ cars registry data or directly from insurance companies to be evaluated as an indicator for the change in behavior as well.

\begin{tabular}{|c|c|c|}
\hline Indicator & Strengths & Weaknesses \\
\hline \multirow{3}{*}{ Change in behavior and attitude } & $\begin{array}{c}\text { Indicators can be easily identified during } \\
\text { observations }\end{array}$ & $\begin{array}{c}\text { Represents single time point for each } \\
\text { individual }\end{array}$ \\
\hline & Pre-intervention data are not available & Potential inter and intra observer variability \\
\hline & $\begin{array}{l}\text { Anticipate short time between intervention } \\
\text { and indicator change }\end{array}$ & Time and resource intensive \\
\hline & Accidents likely captured in police data & \\
\hline Rate of accidents & $\begin{array}{c}\text { Pre- intervention data available for } \\
\text { comparison }\end{array}$ & $\begin{array}{l}\text { Can be influenced by other an evaluated } \\
\text { factors }\end{array}$ \\
\hline \multirow{4}{*}{ Rate of injuries and fatalities } & $\begin{array}{l}\text { Injuries and fatalities likely captured in police } \\
\text { or hospital data }\end{array}$ & $\begin{array}{c}\text { Improvements in injury surveillance system } \\
\text { may bias surveillance }\end{array}$ \\
\hline & $\begin{array}{l}\text { Pre- intervention data available for } \\
\text { comparison }\end{array}$ & Fatalities may be unrelated to accidents \\
\hline & & Can be influenced by an evaluated factors \\
\hline & Misdiagnosis highly unlikely & \\
\hline \multirow{3}{*}{ On line and on site surveys } & Used to tailor public education & Potential interviewer bias \\
\hline & & Time and resource intensive \\
\hline & $\begin{array}{c}\text { Identifies barriers to properly address safety } \\
\text { issues }\end{array}$ & Answer limited by survey design \\
\hline
\end{tabular}

\section{Data Analysis}

A time series study design will be used to assess the campaign effects. This design will be used to analyze data acquired from national reports of injury and fatality rates as well as accidents rates. Using the same reporting source from before the campaign will give us an accurate insight on the change after the campaign. The information, attitude, and principle survey is a quantitative mechanism that is developed using qualitative method of focus group discussion. Although the questions will be answered using a multiple choice format, the available answer choices should come from the most common reasons given during openended questioning in a focus group. Using qualitative methods to develop the survey will allow inclusion of social and cultural factors that may not be apparent to researchers. The disadvantage to this qualitative approach is that is cannot be taken into a large number of subjects. Using the information garnered to formulate the survey will help amplify this information to a larger group in a quantitative fashion. The disadvantage is that the focus group data is being applied to different individuals who may not see their best answer as a choice on the survey. Survey data will be analyzed to find out why people do or don't obey the speeding law or ignore important road safety measures. Identify areas of knowledge deficit on the benefits of road safety measures.

\section{The Dissemination of the plan}

Positive results following successful application of this campaign can be published in major public health journals as well as presented in major international conferences. It would provide a supportive boost for the current road safety plans in terms of improving the outcomes form one side and providing more information to researchers regarding the attitudes and behavior expected from the Egyptian population towards implementing and enforcing road safety measures.

\section{References}

1. WHO (2017) Road Safety in Egypt. Violence and Injury Prevention, WHO, Geneva, Switzerland.

2. World Bank report (2014) 
This work is licensed under Creative Commons Attribution 4.0 Licens DOI: 10.19080/JOJPH.2017.01.555570

\section{Your next submission with Juniper Publishers} will reach you the below assets

- Quality Editorial service

- Swift Peer Review

- Reprints availability

- E-prints Service

- Manuscript Podcast for convenient understanding

- Global attainment for your research

- Manuscript accessibility in different formats

( Pdf, E-pub, Full Text, Audio)

- Unceasing customer service

Track the below URL for one-step submission https://juniperpublishers.com/online-submission.php 